\title{
Mombasa grass characterisation at different heights of grazing in an intercropping system with Babassu and monoculture
}

\section{Caracterização do capim Mombaça em diferentes alturas de pastejo em sistema de consorcio com babaçu e monocultivo}

\author{
Marcos Odilon Dias Rodrigues ${ }^{1 *}$; Antônio Clementino dos Santos ${ }^{2}$; \\ Perlon Maia dos Santos ${ }^{3}$; Jhone Tallison Lira de Sousa ${ }^{1}$; \\ Emerson Alexandrino ${ }^{4}$; Jose Geraldo Donizette dos Santos ${ }^{4}$
}

\begin{abstract}
The aim of this study was to evaluate agronomic and structural traits, as well as root mass, of Panicum maximum $\mathrm{cv}$. Mombasa in different conditions of animal grazing in the same pasture in a monoculture system and a Pasture-Forestry Intercropping System (intercropped with Babassu palm trees). Evaluations were performed from December 2012 to February 2013. The systems were kept under continuous grazing with sheep (20 kg live weight on average) throughout the evaluation period. The design was completely randomised into split plots, in which each plot was the system and the subplots were grazing heights, with three sample cycles. The Babassu palm tree influenced the production of the aerial-part dry matter in the intercropping system due to a decrease in grass tillering caused by shading stress. The root dry matter decreased influenced by shading and intensity of animal grazing in the evaluated heights, leading to a reduction as decreased the grass height. The monoculture system led to better results for the same heights in all parameters in comparison to the intercropping system, including the number of tillers, dry matter production (DM), leaf-area index (LAI) and DM (\%), which were higher in the monoculture system regardless of the assessed heights. The natural shade of Babassu palms negatively affected the productive and structural traits of Panicum maximum cv. Mombasa, thereby altering the grass structure and lowering its productive capacity.
\end{abstract}

Key words: Root dry matter. Number of tillers. Shading.

\section{Resumo}

Objetivou-se com esse trabalho avaliar as características agronômicas, estruturais e massa de raiz do Panicum maximum cv. Mombaça em diferentes condições de pastejo dentro do mesmo pasto em sistema de monocultivo e integrado pastagem-floresta (consorciado com palmeiras de babaçu). Foram realizadas avaliações nos meses de dezembro de 2012 a fevereiro de 2013. Os sistemas foram mantidos sob pastejo contínuo com ovinos (média de $20 \mathrm{~kg}$ de peso vivo) durante todo período de avaliação. O delineamento foi inteiramente ao acaso em parcelas subdivididas, sendo: parcelas os sistemas e subparcelas as alturas de pastejo, com 3 ciclos de coleta. A presença da palmeira do babaçu influenciou a produtividade de massa seca da parte aérea em sistema consorciado devido a diminuição no perfilhamento da gramínea ocasionado pelo estresse do sombreamento. A produção de massa seca de raiz decresceu

\footnotetext{
1 Discentes de Doutorado, Ciência Animal Tropical, Universidade Federal do Tocantins, UFT, Araguaína, TO, Brasil. E-mail: marcosodilon22@gmail.com; jhonelira@hotmail.com

2 Prof., Bolsista de produtividade CNPq, UFT, Araguaína, TO, Brasil. E-mail: clementino@mail.uft.edu.br

3 Prof., Universidade Federal Rural da Amazônia, UFRA, Paraupebas, PA, Brasil. E-mail: perllon_zoo@yahoo.com.br

4 Discentes do Curso de Doutorado, Ciência Animal Tropical, UFT, Araguaína, TO, Brasil. E-mail: e_alexandrino@yahoo.com.br; jhonelira@hotmail.com

Author for correspondence
} 
sendo influenciada pelo sombreamento e pela intensidade de pastejo nas alturas avaliadas, ocorrendo diminuição à medida que decresceu a altura da gramínea. O sistema de monocultivo teve melhores resultados para as mesmas alturas em todos os parâmetros avaliados em comparação com o sistema consorciado, onde número de perfilhos, produção de matéria seca (MS) da parte aérea, índice de área folear (IAF), \% de MS foram maiores em sistema de monocultivo independente das alturas avaliadas. $\mathrm{O}$ sombreamento natural das palmeiras de babaçu influenciou negativamente as características produtivas e estruturais do Panicum maximum cv. Mombaça, alterando dessa forma a arquitetura da gramínea e diminuindo sua capacidade produtiva.

Palavras-chave: Massa seca de raiz. Número de perfilhos. Sombreamento.

\section{Introduction}

The pursuit of pasture recovery methods to improve the efficiency and economy are extremely important for avoiding deforestation of new areas and to contribute to increased productivity (DIASFILHO, 2006). The non-recovery of cultivated pastures directly affects the financial viability of production in grazing systems due to a decrease in the pasture carrying capacity, thus supporting lower stocking per area, as well as resulting in poor weight gain per animal unit (YOKOYAMA et al., 1999). The pressure exerted by environmental agencies through restrictions on opening new areas in order to reduce deforestation makes degraded pasture recovery a determining factor in livestock expansion, particularly in agricultural frontier zones (DIAS-FILHO, 2011).

In the north and northeast regions of Brazil, the largest contingent of Babassu palms is found (IBGE, 2012). Many by products have been studied by researchers in order to replace conventional highpriced feed, such as corn and soybean (MEDEIROS et al., 2009). In the industrial processing of Babassu, some sub and co-products are generated, including those going to mesocarp meal and Babassu cake that can be used as an alternative income to farmers in addition to producing animals in the understory. The use of systems that combine production efficiency with environmental protection has grown in recent years. Therefore, the use of integrated production systems is increasingly growing in farming business. Among these systems, the Pasture-Forestry Intercropping System has been highlighted because it associates tree, pasture and animal production in the same area with the purpose of adding value to the product produced and/or the area.
In the implantation of Pasture-Forestry Intercropping Systems, a key factor in its success is the selection of appropriate forage species, and so it is necessary to know the morphophysiological and productive behaviour of the grass regarding stress, shading and competition for nutrients with the arboreal component. The arboreal component influences most of the morphological and agronomic traits of the existing grass in the understory that is modified due to the arrangement of the trees within the system (PACIULLO et al., 2011).

The Panicum maximum grasses, such as Mombasa grass, have shown similar yields in Silvopastoral systems compared to grazing in full sun, thus demonstrating that it is a grass with high adaptability to the Silvopastoral system, reaching high levels of dry matter production (DM) in shaded systems (SOARES et al., 2009). Despite the changes in its composition, relative to the lower dry matter content produced under shade, grass species change their morphological traits differently in shading situations and so prevent the generalisation of a standard management for grasses within the Pasture-Forestry Intercropping System (CASTRO et al., 1999).

However, despite positive data on the performance of certain grasses in shaded systems being reported in the literature, it is necessary to consider the type of system, the spatial distribution of the trees in the system, and the forage sample position area relative to the position of the trees, as well other factors that influence the productivity of certain species of tropical grasses intercropped with trees. The production, structural composition and grass alter as a function of its growth, therefore changing the proportions of leaf, stem and dead material as the 
grass grows. The forage availability in the area is directly influenced by mowing height, which reduces the leaf/stem ratio and tillering as the sward height raises, as tillering is the main structural trait affected by shading (ALEXANDRINO et al., 2011).

In Pasture-Forestry Intercropping Systems, structural changes such as the greatest stem elongation, reduction of the tiller community, and low leaf-area index (LAI) intensify with shading, resulting in low production per area. Management recommendations regarding mowing height in conventional systems do not adjust for this type of system because the structural and production traits of the grass are modified depending on the adopted shading level. The grass tends to change its leaf anatomy and specific leaf area to increase light absorption efficiency when subjected to different levels of shading through phenotypic plasticity to adjust itself to the changes in light intensity (GOBBI et al., 2011). For tropical grasses of the genres Urochloa and Panicum maximum, shading levels between $25 \%$ and $30 \%$ of the solar radiation have provided production rates similar to areas of full sun (CASTRO et al., 2009).

The aim of this study was to evaluate agronomic and structural traits, as well as root mass, of Panicum maximum cv. Mombasa in different conditions of grazing in the same pasture in Pasture-Forestry Intercropping Systems and a monoculture system.

\section{Materials and Methods}

The evaluated areas of the intercropping system with Babassu and monocultures were located near the farm of the School of Veterinary Medicine and Animal Science of the Federal University of Tocantins, Campus Araguaina - Tocantins, between the geographical longitude of 9213700 and latitude of 9213900 UTM-NS and meridians 810500 and 810780 UTM-EW. According to Köppen (1948), the climate is classified as Aw (hot and humid) with an average annual precipitation of $1800 \mathrm{~mm}$ and maximum temperatures of $40^{\circ} \mathrm{C}$, minimum $18^{\circ} \mathrm{C}$, and an average of $28^{\circ} \mathrm{C}$. The average annual relative humidity is $76 \%$. The soil of the experimental area was classified according to the SiBCS (Brazilian System of Soil Classification) (EMBRAPA, 2006) as Plinthic Eutric Red-Argisol with a maximum slope of $3 \%$.

The total area (intercropping and full sun) has a history of deforestation over the last 25 years using fire, and subsequent implantation of cultivated pasture that was not fertilised and has been poorly managed. Part of the area was soon abandoned after the pasture degradation, resulting in a secondary forest with a strong presence of Babassu palm (Attalea speciosa, Mart) in its floristic composition. The other part of the area was used until 2005 and then also abandoned, resulting in a thin shrubbery.

In the Babassu Forest area, a Pasture-Forestry Intercropping System was established, which is characterised by a Silvopastoral system (SPS) with native tree species (Babassu) with Mombasa grass (Panicum maximum Jacq.). The area was thinned by hand, preserving the palm trees. The thinning was done until $30 \%$ shading, giving rise to an intercropping system with $30 \%$ interception of full brightness. The shading adjustment of the area was carried out from the measurement of illuminance (Lux) with the aid of a lightmeter (model LD 200, Instrutherm). These measurements were made at 50 points within the SPS in a mesh constructed equidistantly and to be representative $(8 \times 8)$. The light measurements were made between 11:30 a.m. and 1 p.m. with the noonday sun, and were compared with the measurements of the full-sun area (FS). The measurements were performed at the beginning of the evaluation period. From these measurements, the percentage of shading area was calculated as follows:

$100-\{($ SPS measurement/FS measurement $) \mathrm{x}$ $100\}$.

The area with shrubbery was mowed and treated with herbicide, giving rise to the conventional system of grazing production (Full Sun). The dimensions of each area (system) were: Full Sun: 6,500 $\mathrm{m}^{2}$ and Intercropped: 7,042.2 $\mathrm{m}^{2}$. 
The climatic conditions of the system during the trial period were monitored with a portable weather station (model Tycon Tp-1080wc, Pro Weatherstation - R) from December 2012 to February 2013. The evaluated weather data included: relative humidity $(\%)$, temperature $\left({ }^{\circ} \mathrm{C}\right)$ and precipitation (mm) (Figures 1, 2, 3).
The correction and fertilisation of the area was performed according to the results shown in Table 1, in which data for soil analysis were taken before the implantation of the experiment. Nitrogen fertilisation was $100 \mathrm{~kg} \mathrm{~N} \mathrm{ha}^{-1}$, regardless of the area, which was carried out during the stabilisation phase (coverage) of the grass as recommended by Collier et al. (2008).

Figure 1. Weekly relative humidity (\%) regarding the experimental evaluation period in the monoculture and intercropping systems.

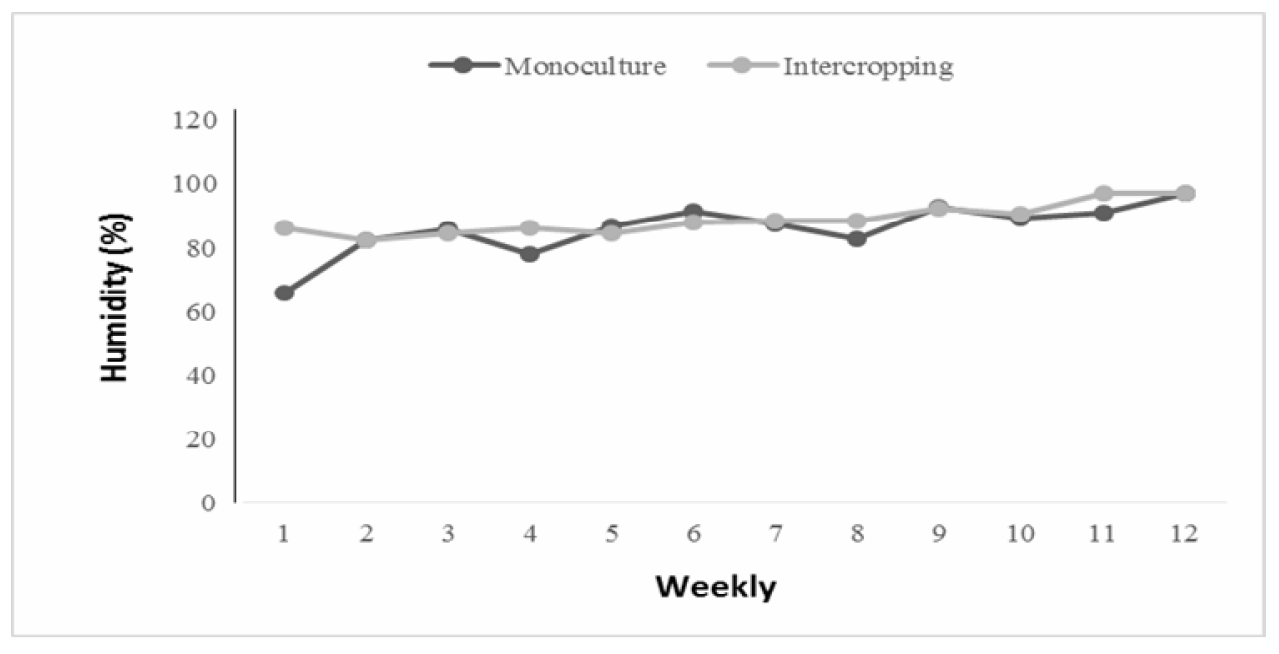

Figure 2. Weekly temperature $\left({ }^{\circ} \mathrm{C}\right)$ regarding the experimental evaluation period in the monoculture and intercropping systems.

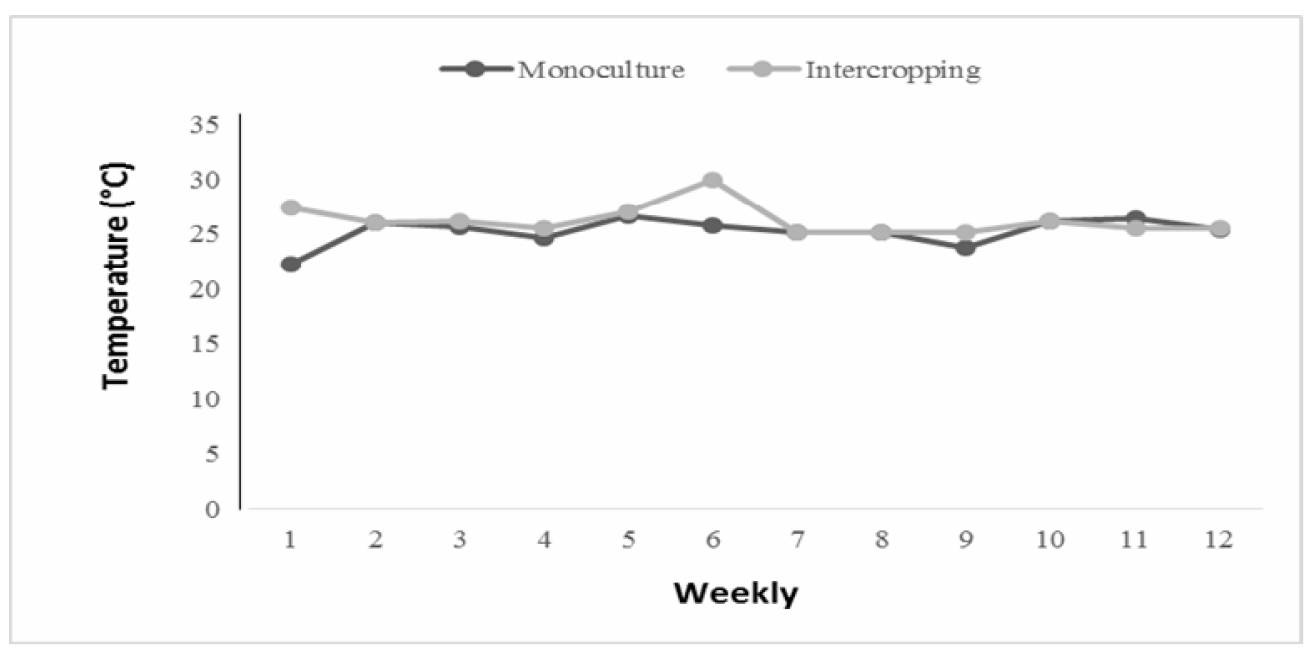


Figure 3. Weekly precipitation regarding the experimental evaluation period in the monoculture and intercropping systems.

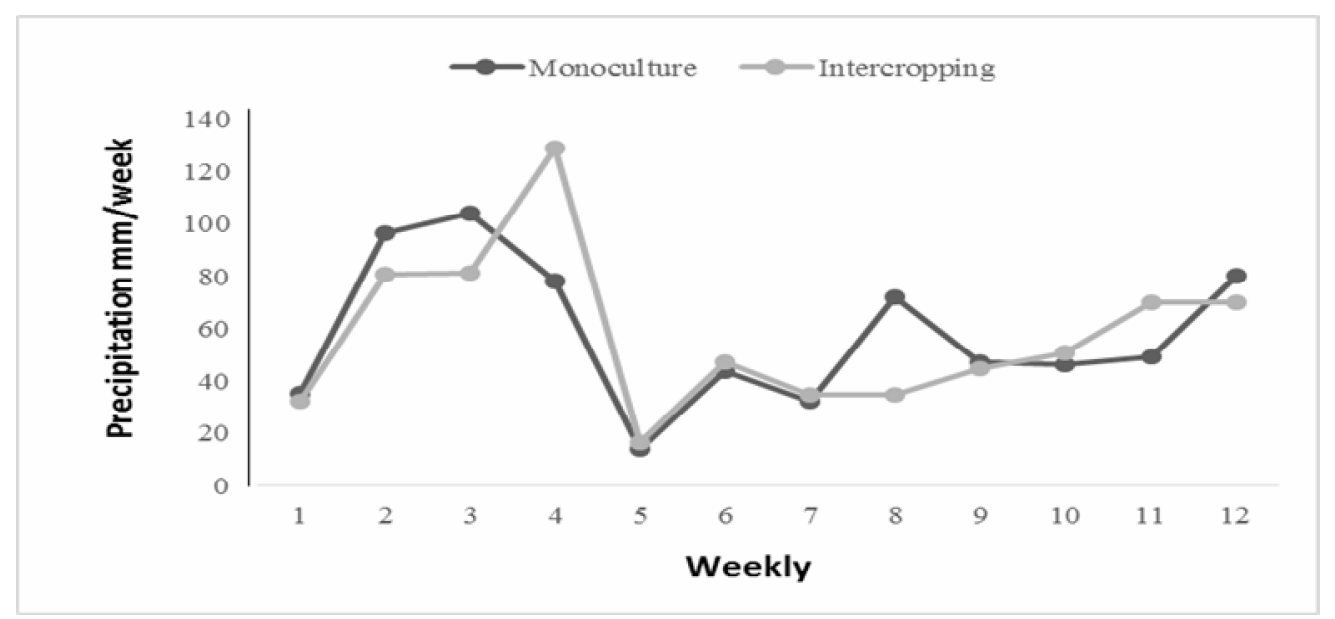

Table 1. Chemical properties of the soil at $0-20-\mathrm{cm}$ depth in the Pasture-Forestry Intercropping System and monoculture systems.

\begin{tabular}{|c|c|c|c|c|c|c|c|c|c|}
\hline \multicolumn{10}{|c|}{ Results } \\
\hline \multicolumn{8}{|c|}{ cmolc/dm ${ }^{3}$} & \multicolumn{2}{|c|}{$\mathrm{mg} / \mathrm{dm}^{3}(\mathrm{ppm})$} \\
\hline System & $\mathrm{Ca}$ & Mg & Al & $\mathrm{H}+\mathrm{Al}$ & $\mathbf{K}$ & CTC & SB & $\mathbf{K}$ & P (Mel) \\
\hline Monoculture & 8.0 & 1.35 & 0.00 & 2.23 & 0.17 & 13.59 & 11.36 & 66.02 & 11.87 \\
\hline \multirow[t]{2}{*}{ Intercropping } & 3.3 & 0.52 & 0.00 & 3.78 & 3.78 & 9.34 & 5.56 & 30.54 & 9.24 \\
\hline & \multicolumn{2}{|c|}{ Mat. Org } & \multicolumn{2}{|c|}{ pH } & & \multicolumn{4}{|c|}{ Textura (g/kg) } \\
\hline System & $(\%)$ & $(\mathrm{g} / \mathrm{kg})$ & $\mathrm{CaCl}_{2}$ & $\mathrm{H}_{2} \mathrm{O}$ & $\mathrm{V}(\%)$ & Sand & Silt & & \\
\hline Monoculture & 3.8 & 38.33 & $5.44^{2}$ & 6.31 & 83.61 & 566.28 & 138.3 & & \\
\hline Intercropping & 3.5 & 35.82 & 5.06 & 5.97 & 59.53 & 616.28 & 154.9 & & \\
\hline
\end{tabular}

Mombasa grass was sown on all systems. Planting in November 2011 was performed manually at a seeding rate of $13 \mathrm{~kg} \mathrm{ha}^{-1}$ of pure live seeds. After 5 months of stabilisation, mechanical cutting to $50 \mathrm{~cm}$ was carried out, and sheep were introduced into the area according to the carrying capacity in a continuous grazing system to maintain the height target of $50 \mathrm{~cm}$.

The experimental design was completely randomised into split plots, with four repetitions of each mowing height in which the plots were systems (monoculture and intercropped with Babassu), and the subplots were mowing heights, which were set at 30, 40 and $50 \mathrm{~cm}$. Twenty-eight days after the entry of the animals into the area, was carried out the identification of the assessment locations determined from the mowing heights. The mean mowing height was $50 \mathrm{~cm}$ in both areas. From that point, each mowing height was evaluated with the aid of a graduated scale in $\mathrm{cm}$.

To determine the average height of each assessed mowing height, measurements were made at 10 specific points of each area with the aid of a graduated scale where the plant height was measured from the soil level to the curvature of the last expanded leaf. The determination of mowing areas in the continuous grazing system was possible due to the variability in the grazing by animals that was uneven within the area. For each pasture condition, four replications were randomly assigned, totalling twelve points for each assessed system. On the measurement day, the mowing heights were assessed at those points using a graduated scale. 
Productive and structural traits evaluated in the two systems at different heights were: total fresh matter (TFM), total dry matter (TDM), leaf dry matter (LDM), stem dry matter (SDM), senescent material dry matter (SMDM), dry matter percentage (DM\%), partition of morphological components (leaf, stem and senescent material), leaf-area index (LAI), forage density $\left(\mathrm{kg} / \mathrm{cm}^{3}\right)$, leaf:stem ratio $(\mathrm{L} / \mathrm{S})$, tiller number and root dry matter (RDM). To determine leaf, stem and senescent material dry matter, total fresh matter and aerial-part dry matter, a rectangle of $1 \times 0.5 \mathrm{~m}$ was used. To assess forage dry matter availability of each treatment within each evaluated system, the cutting height was 20 $\mathrm{cm}$ above ground level for the samples, which were weighed and subsampled to determine the total productivity/area and the dry mass of morphological components of the grass. To determine the number of tillers for each assessed area, tillers were counted with the aid of a rectangle of $1 \times 0.15 \mathrm{~m}$.

After weighing, the samples were divided into two subsamples. The first subsample components were leaves, stems and senescent material, which were separated and weighed, and after weighing they were oven-dried at $65^{\circ} \mathrm{C}$ for 72 hours to determine the dry matter. The second subsample was used to determine the LAI. The evaluation of the root mass was performed by the auger method as recommended by (FUJIWARA et al., 1994). The extraction of the samples was made with an auger of $7.1-\mathrm{cm}$ internal diameter $\left(0.79-\mathrm{dm}^{3}\right.$ volume $)$ with a serrated base. The soil samples with the root of each point sampled at $0-20-\mathrm{cm}$ depth were washed in a sieve with a 2-mm mesh, separated from impurities (soil and straw) and weighed in a semi-analytical scale, and then oven-dried at $65^{\circ} \mathrm{C}$ for 72 hours to determine root dry matter. To obtain the data for each sample, for each repetition of each height within the areas, a total of three samples were collected and averaged for each repetition.

Data regarding agronomic and structural production and root mass were subjected to analysis of variance and the means were compared by the
Tukey test at $5 \%$ probability. All statistical analyses were performed using Assistat software (SILVA; AZEVEDO, 2002).

\section{Results and Discussion}

The more selective habit of grazing animals was what kept mowing heights throughout cycle. Animals prioritised regions of lower mowing heights due to a higher leaf/stem ratio, resulting in greater availability of leaves, but an average height of the systems of $50 \mathrm{~cm}$ was maintained. The factors that influence the dynamics of change in sward structure are directly linked to changes in the proportions of defoliation rates by animals and the growth of plants, which are modified according to the height of the grass and leaf, as well as the proportion of stems and senescent material present in the canopy (SANTOS et al., 2010).

There was an interaction between the assessed heights and the systems for the aerial-part dry matter (Figure 4). The percentage of dry matter was higher in the assessed heights in the monoculture system compared to the system intercropped with Babassu, similar only at $40 \mathrm{~cm}$ height, which in both systems did not differ statistically for dry matter percentage (Figure 4). The same was reported by Souza et al. (2007) who found that shading significantly affected the dry matter content of forage due to a higher proportion of leaves and a higher ratio of living:dead material on grass. According to Gobbi et al. (2011), another factor that reduces dry matter content of the grass in the shaded system is leaf anatomy modification because the increased specific leaf area leads to a decrease in the forage mass density and reduces sclerenchymatous tissue and the thickness of the palisade parenchyma.

Dry matter percentage did not differ between the 40- and 50-cm heights (Figure 4) in the monoculture system. There was a difference at the $30-\mathrm{cm}$ height, which had a higher dry matter content (\%) than the other assessed heights (Figure 4) due to a greater percentage of senescent material dry matter $(46.7 \%)$. 
For total fresh matter in the intercropped system, there was no significant difference between the assessed heights, but there was a significant difference in the percentage of dry matter at $40 \mathrm{~cm}$ compared to the other heights (Figure 4). The LAI (Figure 5) showed an interaction between systems (monoculture and intercropped) and mowing heights in each area. The greatest LAI for the period occurred in the pasture monoculture system in comparison to the same assessed heights in the intercropping system (Figure 5). According to Reis et al. (2013) who evaluated the productivity of Marandu grass under shade and full sun, LAI values in full sun were close to the ideal light interception compared to the grass in the shaded system in the same time interval and with the same height conditions. Therefore, shading was considered the main influential factor in the plants' response to the increase in LAI. According to Paciullo et al. (2007), the lower the incidence of light that enters the wood, the lower the LAI and tiller density in the understory.

In the monoculture system, the LAI (Figure 5) was higher at a height of $50 \mathrm{~cm}$ during the study period. This result is related mainly to the greater length and availability of leaves at higher pasture layers, which results in a higher LAI, whereas the lower LAI rate was at $30 \mathrm{~cm}$ in the monoculture system (Figure 5). In the intercropping system, the highest LAI (Figure 5) followed the same pattern of grazing heights as in the monoculture system, and during the evaluation period, the $50-\mathrm{cm}$ height was superior to the other evaluated heights. The low yields of TFM, LDM, SDM, LAI, L/S ratio and RDM in the intercropping system, according to Cargnelutti-Filho et al. (2004), can be directly attributed to three factors: competition for light, water and nutrients in addition to the competition for space between the root and aerial part of the plants that comprise the intercropping (OLIVEIRA et al., 2007). Another important factor is the cycling and deposition of nutrients, which are essential for maintaining the productivity of the intercropping system, particularly in transitional regions of Cerrado-Amazon (SILVA NETO et al., 2015).
There was an interaction between the evaluated systems and the different grazing heights for the L/S ratio (Figure 6). The L/S ratio is one of the most important structural traits as it has a direct effect on the quality of available forage in the pasture, and this relationship directly affects the pasture structure and animal grazing. With increasing sward height, there was a decrease in the relationship between the existing leaves and stems in the pasture, and the highest L/S ratio was found in the area of lower grazing heights. The increase in sward height resulted in a higher production of stems to adjust the canopy structure and to improve the efficiency of use of light by the lower leaves in both the monoculture and intercropped systems (Figure 6). According to Lacerda et al. (2009) who evaluated different regrowth ages of Andropogon grass in Silvopastoral system, besides the shadowing effect on the $\mathrm{L} / \mathrm{S}$ ratio, the greatest regrowth time resulted in a lower L/S ratio, occurring quadratic effect for this pasture structure trait as it raised the regrowth time in addition to the canopy height, affecting this relationship. The $\mathrm{L} / \mathrm{S}$ ratio in the monoculture system in this experiment showed the same pattern of distribution compared to the grazing heights measured in the intercropping system (Figure 6).

Although the $\mathrm{L} / \mathrm{S}$ ratio was similar at 50 and 40 $\mathrm{cm}$ in both systems, the grass in the intercropping system started to invest more in leaf elongation than in the stems (Figure 6). Despite this adjustment in canopy structure, the TDM production $\mathrm{ha}^{-1}$ was lower in the shaded system because of individual plant investment prioritising the aerial part. In shaded environments, the $\mathrm{L} / \mathrm{S}$ ratio tends to increase due to reduced light.

In the intercropping system, besides the height influences on the $\mathrm{L} / \mathrm{S}$ ratio, at different grazing heights, there is also an effect of shading generated by the forest that directly influenced the grass structure (Figure 6). This led to changes in leaf structure, which had marked development and became more tender and etiolated as adaptive adjustments, seeking greater efficiency for capturing light (SOARES et 
al., 2009). The larger L/S ratio occurred at a height of $30 \mathrm{~cm}$ with no difference between the systems for such traits. There was an interaction in all cycles between the production systems (monoculture and intercropping) and evaluated heights (Figure 7) related to the number of tillers. This interaction may be linked to the influence of the system on the number of tillers in each grazing height, which the desired amount of tillers for each area depended on the system type and pasture height condition evaluated because both systems (monoculture and intercropping), acted differently on the number of tillers/area.

Figures 4, 5, 6, 7. Percentage (\%) of Dry Mass, LAI, L/S ratio, and number of Mombasa grass tillers $/ \mathrm{m}^{2}$ in monoculture and intercropped systems with Babassu. CV (\%): 8.41, 17.57, 14.15, and 10.72, respectively. Lowercase letters compare mowing heights between the systems. Uppercase letters compare the situations of grazing within the system.
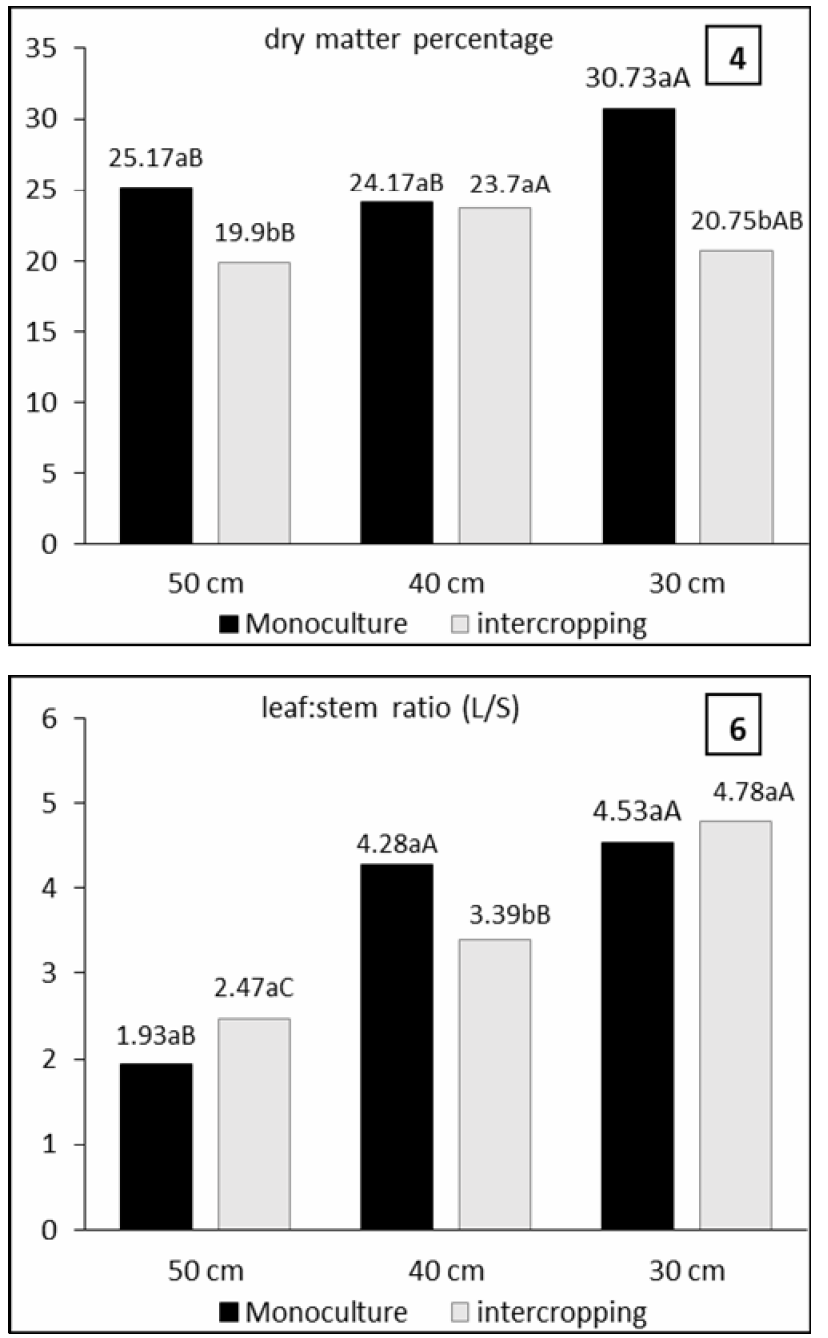

The monoculture system had the highest number of tillers in all evaluated cycles when compared to intercropping (Figure 7). The number of tillers is directly related to the DM production and this is a variable that is strongly influenced by the natural
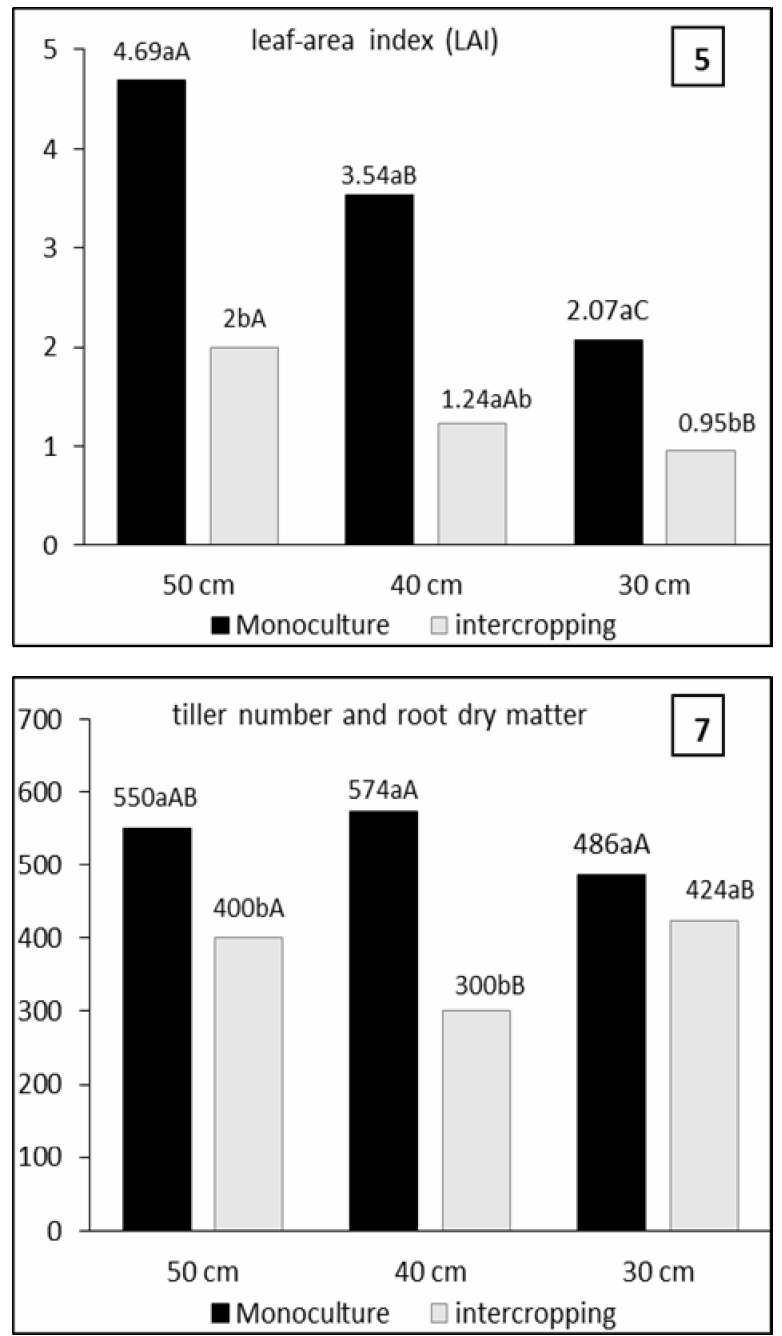

shade because it changes the ratio of incident Red/Far-Red radiation, thus directly affecting the quality and quantity of light reaching the understory (PACIULLO et al., 2007). This changes the number of tillers/area in shaded environments and affects 
the appearance of new tillers (PACIULLO et al., 2008). In the monoculture system, there was no significant difference in the number of tillers between 50-, 40- and 30-cm heights (Figure 7). Even though the literature reports that the height influences the amount of tillers per area, in the monoculture system, a height of up to $50 \mathrm{~cm}$ did not require modifications to the tiller community in these management conditions (Figure 7). The fact that this change does not have occurred in the tillers community in monoculture pasture may have been influenced by selective grazing of animals and the higher incidence of light inside the forage layer which favoured tillering (Figure 7). Alexandrino et al. (2011), who evaluated different heights of Mombasa grass, observed that by raising the sward height, there is a reduction in the amount of tillering and an increase in the tiller height. In this study, this occurred only in the intercropping system, for the same measured heights, and at 50, 40 and $30 \mathrm{~cm}$ (Figure 7) were significantly different. The $30-\mathrm{cm}$ height had the highest number of tillers compared to the 50- and 40-cm heights during the study period.

For the aerial-part dry matter production (TDM), there was an interaction between the production systems (monoculture and intercropping) and the assessed heights for TDM (Figure 8). The monoculture system had the greatest TDM production, which was higher than the intercropping system regardless of height. The lower production rates in the intercropping system, according to Carvalho et al. (2002), are related to the influence of shading on the grass, which changes the incidence of solar radiation in the understory, as well as the tree distribution and competition for water and nutrients between the tree component and the grass (PACIULLO et al., 2011). The modification of the photosynthetically active radiation by shading affects the photosynthetic pathway and translocation of photoassimilates of tropical grasses that display the $\mathrm{C}_{4}$ photosynthetic pathway (DIAS-FILHO, 2000), which is the main limiting factor to pasture productivity in intercropping with trees in shading level adopted that could compromise forage growth (BELESKY, 2005). Comparing the grazing heights within the systems, the largest TDM production occurred at 50 and $40 \mathrm{~cm}$ in the intercropping system (Figure 8).

The 30-, 40- and 50-cm assessed heights in the pasture monoculture system differed significantly with increased TDM production at $50 \mathrm{~cm}$, which was higher than the 40-cm height, which in turn was higher than at $30 \mathrm{~cm}$ (Figure 8). In both evaluated systems, the $50-\mathrm{cm}$ heights had the highest TDM availability due to the higher proportion of leaf, stem and senescent materials in these areas. The lowest rates were found at $30 \mathrm{~cm}$ in the monoculture and intercropping systems. Total dry matter availability and herbage accumulation have a positive correlation with sward height, which is associated with higher productivity in the higher sward height, regardless of the proportion of leaf, stem and senescent materials (ALEXANDRINO et al., 2011).

For leaf dry matter availability (LDM), an interaction was observed between the evaluated systems (monoculture and intercropping) and heights (Figure 9). The highest LDM production rates were found in the monoculture system compared to intercropping because this trait is directly influenced by the number of tillers/area (Figure 9). The low LDM production in the intercropping system was influenced by the lower number of tillers and the selective grazing of animals, as they have a diet almost completely based on leaves, due to the higher nutritional value compared to the stem and senescent material (BRÂNCIO et al., 2003).

The LDM availability rate in the monoculture system differed between the assessed heights, with an increase in this trait with increasing pasture height (Figure 9). In the intercropping system, LDM production was similar between the assessed heights, and at 50 and $40 \mathrm{~cm}$, there was no significant difference (Figure 9). The lower leaf production in the intercropping system compared to monoculture 
for the same heights is an indication that in systems that use both trees and grasses, stocking rates should be lower when working with continuous grazing, requiring a larger amount of leaf blade available to animals for grazing and for keeping a higher amount of remaining leaves in grass for conducting photosynthesis. According to Dias-Filho (2000), the shaded grass system has a higher leaf elongation rate, a positive relative growth rate and lower tillering rate, and a less extensive root system, which can affect the grass productivity under stress by burning or grazing. With the decrease in the root system, the grass nutrition is impaired due to insufficient support of nutrients and water for recovery after defoliation, which directly affects the productivity and persistence of tillering in shading system.

Figures 8, 9, 10, 11. Total dry matter, leaf, stem and senescent material in $\mathrm{t} /$ ha of Mombasa grass in the monoculture system and intercropping with Babassu. CV (\%): 9.41, 15.37, 10.29, and 17.80, respectively. Lowercase letters compare the mowing heights between systems. Uppercase letters compare the grazing within the system.
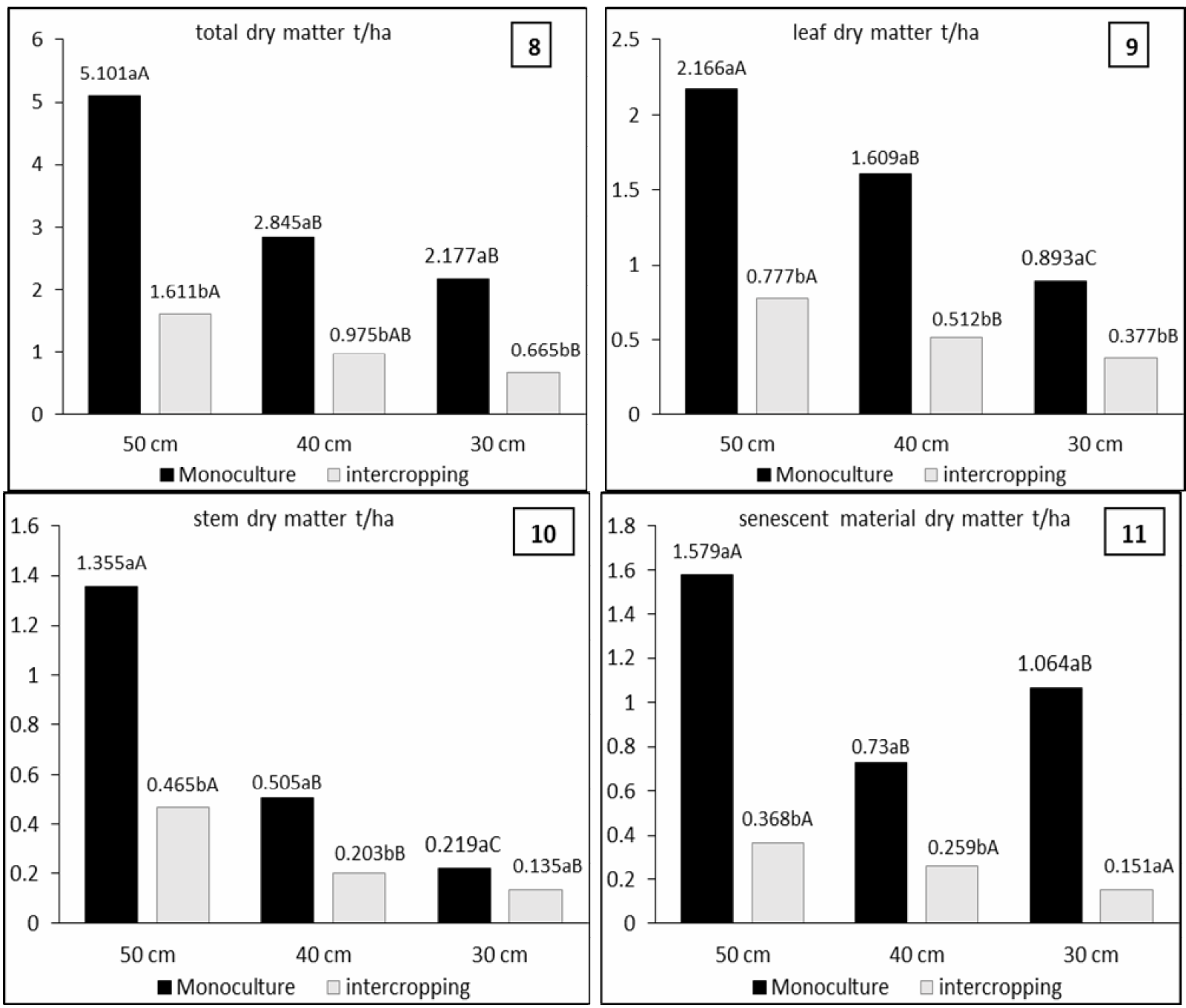

There were differences between the monoculture due to the higher plant population in the area and intercropping systems regarding the assessed heights for stem dry matter (Figure 10). The highest SDM yields were found in the monoculture system compared to the population in the intercropping system. According to Paciullo et al. (2008), who evaluated different intensities of shade, the SDM 
showed a positive correlation with the increase in tiller density. In the monoculture system, as the LDM production increased, there was an increase in the SDM production (Figure 10). The increase in stem production was linked to the plant fit over the height elevation that changes attempting to expand its light absorption capacity. In the intercropping system, the opposite effect occurred, and the increase in LDM production had a negative correlation with the production of SDM (Figures 9 and 10), proving that the grass in shaded system will invest more in foliar area than in stem elongation to seek greater efficiency in capturing the light that enters the understory.

The SDM was influenced by the type of system in which the animals were grazing in (monoculture or intercropping) acted independently in each height influencing the DM productions of components: leaves, stem and dead material (Figures 9, 10, 11). The SDM production in the monoculture system was highest at $50 \mathrm{~cm}$, which this was not statistically significant (Figure 10).

There was an interaction between the monoculture and intercropping systems and the different grazing heights for senescent material dry matter (Figure 11). The quantity of SMDM produced in each area had a similar behaviour in both systems (Figure 11). The largest SMDM production occurred in the monoculture system regardless of grazing heights (Figure 11) compared to the intercropping system. This was due to the grass development speed in the shading system being slower, thus modifying the tiller senescence time, which is affected by factors such as shading level, intercepted brightness level, relative humidity and high content of soil moisture (CASTRO et al., 1999). Shading slows the reproductive stage of the grass, which may be related to the higher vegetative stage time in this particular environment imposed by the woods (CARVALHO et al., 2002).

The SMDM production in the intercropping system did not differ between assessed heights
(Figure 11). In the monoculture system, the largest SMDM rates occurred at $50 \mathrm{~cm}$ and may have been caused by shading of the lower leaves, resulting in increased SMDM production at greater heights (Figure 11). At 40 and $30 \mathrm{~cm}$, the SMDM production was not significantly different to the monoculture system.

There was an interaction between systems (monoculture and intercropping) and grazing heights for root dry matter production (RDM) (Figure 12). The monoculture system had the highest RDM production (Figure 12) compared to intercropping, and with the intensified animal grazing there was a decrease in RDM production (Figure 12).

The root dry matter (Figure 12) in the effective layer of soil used by the grass was influenced by height and shading, and the highest RDM rates were found at 50,40 and $30 \mathrm{~cm}$, respectively, independently of the systems. Another factor besides animal grazing that influenced RDM production (Figure 12) in the shaded system was the effect of woods on the grass, which affected the root development in this type of system, making the plant prioritise the aerial part for light capture rather than absorption of nutrients. The Pasture-Forestry Intercropping System tends to stimulate higher leaf and stem elongation in the grass in order to adjust the light capture in this type of environment, leading to a decrease in the root system of the grass, thus affecting the absorption capacity (CAMPOS et al., 2007; DIAS-FILHO, 2000). The RDM production has a negative correlation with shading and decreasing linear response in the root production as intensifies shading, reducing up to $93 \%$ the root system (MARTUSCELLO et al., 2009). A change in the biomass allocation pattern of grass under shade favours the development of the aerial part rather than the root system (PACIULLO et al., 2010).

The highest forage density ratios (Figure 13) occurred in the monoculture system for 50- and $40-\mathrm{cm}$ heights and were directly related to the higher number of tillers for those heights (Figure 
7) compared to the intercropping system. When compared to the heights within the system, the 50and 40-cm heights did not differ statistically from each other for forage density (Figure 13) and only at $30 \mathrm{~cm}$ was there a difference, with a lower forage density rate.

In the intercropping system, there was no significant difference between the three assessed heights, and regardless of height, forage density ratios did not differ among themselves. However, it is noted that forage density in the monoculture system tended to increase as the grass height rises, but this was not seen in the intercropping system in which the forage density rate was virtually unchanged by grazing height.

Figures 12, 13. Root dry matter $t /$ ha, forage density ratios of Mombasa grass in the monoculture system and intercropping with Babassu. CV (\%): 14.11 and 16.37. Lowercase letters compare mowing heights between the systems. Uppercase letters compare the grazing within the system.

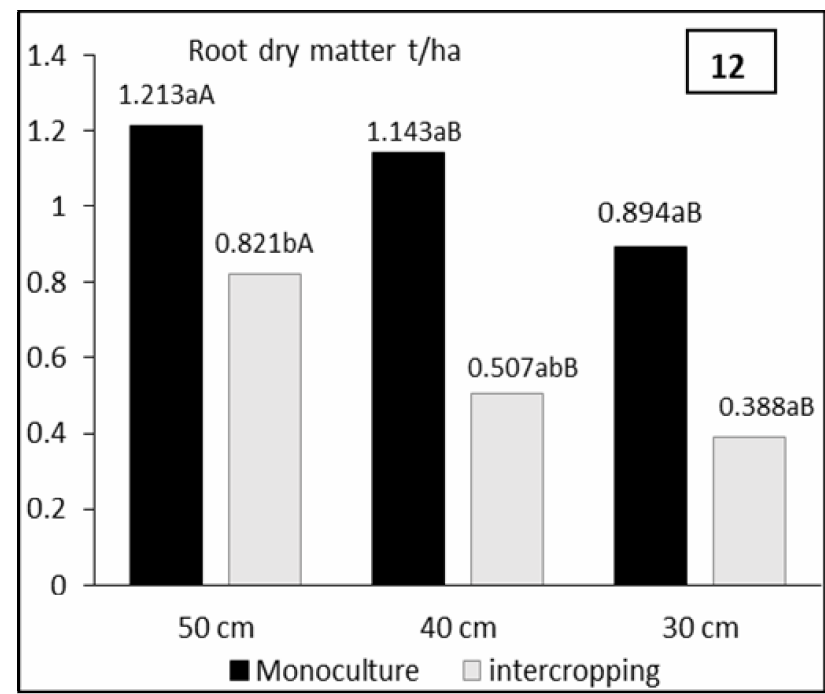

\section{Conclusions}

The natural shade of Babassu palms negatively affects the productive and structural traits of Panicum maximum cv. Mombasa, thereby altering the grass structure and its productive capacity. It is necessary to develop specific management methods for grazing in the Pasture-Forestry Intercropping Systems.

Little is known about the mechanisms that act regulating grass production on light stress. More studies must be performed in order to elucidate the mechanisms that govern the production of tropical forages in the Pasture-Forestry Intercropping Systems.

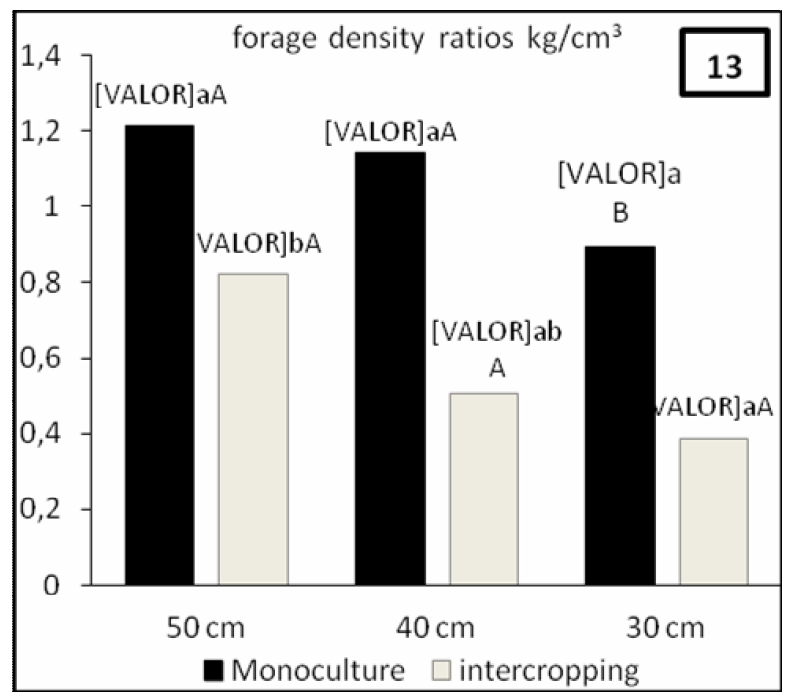

\section{Acknowledgments}

We thank CAPES for the scholarship. For the Public Notice: 047/2012 Pro-Amazon: biodiversity and sustainability/CAPES. The Support Program for Excellence Centers/PRONEX/ SECT/CNPq. These projects have supported the research. The National Council for Scientific and Technological Development (CNPq) for the Research Productivity Grant. 


\section{References}

ALEXANDRINO, E.; CANDIDO, M. J. D.; GOMIDE, J. A. Fluxo de biomassa e taxa de acúmulo de forragem em capim Mombaça mantido sob diferentes alturas. Revista Brasileira de Saúde Produção Animal, Salvador, v. 12, n. 1, p. 59-71, 2011.

BELESKY, D. P. Growth of Dactylis glomerata along a light gradient in the central Appalachian region of the eastern USA: I. Dry matter production and partitioning. Agroforestry Systems, Missouri, v. 65, n. 2, p. 81-90, 2005.

BRÂNCIO, P. A.; NASCIMENTO JUNIOR, D.; EUCLIDES, V. P. B.; FONSECA, D. M.; ALMEIDA, R. G.; MACEDO, M. C. M.; BARBOSA, R. A. Avaliação de três cultivares de panicum maximum jacq. sob pastejo: composição da dieta, consumo de matéria seca e ganho de peso animal. Revista Brasileira de Zootecnia, Viçosa, MG, v. 32, n. 5, p. 1037-1044, 2003.

CAMPOS, N. R.; PACIULLO, D. S. C.; BONAPARTE, T. P.; GUIMARÃES NETO, M. M.; CARVALHO, R. B.; TAVELA, R. C.; VIANA, F. M. F. Características morfogênicas e estruturais da Brachiaria decumbens em sistema silvipastoril e cultivo exclusivo. Revista Brasileira de Biociências, Porto Alegre, v. 5, n. 2, p. 819821, 2007.

CARGNELUTTI-FILHO, A.; CASTILHOS, Z. M. Z.; STORCK, L.; SAVIAN, J. F. Análise de repetibilidade de caracteres forrageiros de genótipos de Panicum maximum, avaliados com e sem restrição solar. Revista Ciência Rural, Santa Maria, v. 34, n. 3, p. 723-729, 2004.

CARVALHO, M. M.; FREITAS, V. P.; XAVIER, D. F. Inicio de florescimento, produção e valor nutritivo de gramíneas tropicais sob condições de sombreamento natural. Revista de Pesquisa Agropecuária Brasileira, Brasília, v. 37, n. 5, p. 717-722, 2002.

CASTRO, C. R. T.; GARCIA, R.; CARVALHO, M. M.; COUTO, L. Produção forrageira de gramíneas cultivadas sob luminosidade reduzida. Revista Brasileira de Zootecnia, Viçosa, MG, v. 28, n. 5, p. 919-927, 1999.

CASTRO, C. R. T.; PACIULlO, D. S. C.; GOMIDE, C. A. M.; MÜLLER, M. D.; NASCIMENTO JUNIOR, E. R. Características agronômicas, massa de forragem e valor nutritivo de brachiaria decumbens em sistema silvipastoril. Revista Pesquisa Florestal Brasileira, Brasília, n. 60, p. 19-25, 2009.

COLLIER, S. L.; LARA, M. A. S.; VILELA, L.; SIRQUEIRA, F. L. T. Recomendação de adubação e calagem a partir do manejo da fertilidade de solos cultivados com pastagens no cerrado. In: ALEXANDRINO, E.; NEIVA, J. N. M.; SANTOS, A.
C.; PERICO, A.; GOMIDE, C. A. M.; CASTRO, C. R T.; PACIULLO, D. S. C.; NÓBREGA, E. B. SIRQUEIRA, F. L. T.; NEGREIROS, J. V. N.; PAIVA, J. A.; ARAUJO, L. C.; VILELA, L.; RIBEIRO, L. A. M.; STEFANELLI, M. A. L.; GUIMARÃES, M. P. A. J.; ZAMBOM, M. A.; SANTOS, M. P.; LEITE, R. L. L.; MARCEDO, R.; SILVA, S. P. N.; DIM, V. P. (Org.). Do campus para campo: manejo de solo sob pastagens. Goiânia: Impacto, 2008. cap. 1, p. 12-63.

DIAS-FILHO, M. B. Growth and biomass allocation of the c grasses brachiaria brizantha and b. humidicola under shade. Revista Pesquisa Agropecuária Brasileira, Brasília, v. 35, n. 12, p. 2335-2341, 2000.

Os desafios da produção animal em pastagens na fronteira agrícola brasileira. Revista Brasileira Zootecnia, Viçosa, MG, v. 40, p. 243-252, 2011. Suplemento Especial.

Sistemas sivilpastoris na recuperação de pastagens tropicais degradadas. In: GONZAGA NETO, S.; COSTA, R. G.; PIMENTA FILHO, E. C.; CASTRO, J. M. da C. (Ed.). SIMPÓSIO DA REUNIÃO ANUAL DA SOCIEDADE BRASILEIRA DE ZOOTECNIA, 43., João Pessoa, 2006. Anais... João Pessoa: SBZ, UFPB, 2006. p. 535-553.

EMPRESA BRASILEIRA DE PESQUISA AGROPECUÁRIA - EMBRAPA. Centro Nacional de Pesquisa de Solos. Sistema brasileiro de classificação de solos. Rio de Janeiro, 2006. 306 p.

FUJIWARA, M.; KURACHI, S. A. H.; ARRUDA, F. B.; PIRES, R. C. M.; SAKAI, E. A técnica de estudo de raízes pelo método do trado. Campinas: Instituto Agronômico de Campinas, 1994. 9 p. (Boletim técnico, 153).

GOBBI, K. F.; GARCIA, R.; VENTRELLA, M. C.; GARCEZ NETO, A. F.; ROCHA, G. C. Área foliar específica e anatomia foliar quantitativa do capimbraquiária e do amendoim-forrageiro submetidos a sombreamento. Revista Brasileira Zootecnia, Viçosa, MG, v. 40, n. 7, p. 1436-1444, 2011.

INSTITUTO BRASILEIRO DE GEOGRAFIA E ESTATÍSTICA - IBGE. Anuário Estatístico do Brasil/ Fundação Instituto Brasileiro de Geografia e Estatística. Produção da Extração Vegetal e da Silvicultura, Rio de Janeiro, v. 27, p. 1-63, 2012.

KÖPPEN, W. Climatologia: con un estudio de los climas de la tierra. México: Fondo de Cultura Econômica, 1948. $479 \mathrm{p}$.

LACERDA, M. S.; ALVES, A. A.; OLIVEIRA, M. E.; ROGÉRIO, M. C. P.; CARVALHO, T. B.; VERAS, V. S. Composição bromatológica e produtividade do capimandropógon em diferentes idades de rebrota em sistema 
silvipastoril. Revista Acta Scientiarum. Animal Sciences, Maringá, v. 31, n. 2, p. 123-129, 2009.

MARTUSCELLO, J. A.; JANK, L.; GONTIJO NETO, M. M.; LAURA, V. A.; CUNHA, D. N. F. V. Produção de gramíneas do gênero Brachiaria sob níveis de sombreamento. Revista Brasileira Zootecnia, Viçosa, MG, v. 38, n. 7, p. 1183-1190, 2009.

MEDEIROS, G. R.; CARVALHO, F. F. R.; BATISTA, A. M. V.; BATISTA, A. M. V.; DUTRA JUNIOR, W. M.; SANTOS, G. R. A.; ANDRADE, D. K. B. Efeito dos níveis de concentrado sobre as características de carcaça de ovinos Morada Nova em confinamento. Revista Brasileira de Zootecnia, Viçosa, MG, v. 38, n. 4, p. 718727, 2009.

OLIVEIRA, T. K.; MACEDO, R. L. G.; VENTURIN, N.; BOTELHO, S. A.; HIGASSHIKAWA, E. M.; MAGALHÃES, W. M. Radiação solar no sub-bosque de sistema agrossilvipastoril em diferentes arranjos estruturais. Revista Cerne, Lavras, v. 13, n. 1, p. 40-50, 2007.

PACIULLO, D. S. C.; CAMPOS, N. R.; GOMIDE, C. A. M.; CASTRO, C. R. T.; TAVELA, R. C.; ROSSIELLO, R. O. P. Crescimento de capim-braquiária influenciado pelo grau de sombreamento e pela estação do ano. Pesquisa Agropecuária Brasileira, Brasília, v. 43, n. 7, p. 917-923, 2008.

PACIULLO, D. S. C.; CARVALHO, C. A. B.; AROEIRA, L. J. M.; MORENZ, M. J. F.; LOPES, F. C. F.; ROSSIELLO, R. O. P. Morfofisiologia e valor nutritivo do capim-braquiária sob sombreamento natural e a sol pleno. Pesquisa Agropecuária Brasileira, Brasília, v. 42, n. 4, p. 573-579, 2007.

PACIULlO, D. S. C.; CASTRO, C. R. T.; GOMIDE, C. A. M.; FERNANDES, P. B.; ROCHA, W. S. D.; MÜLLER, M. D.; ROSSIELO, R. O. P. A densidade do solo e partição de biomassa de Brachiaria decumbens em sistema silvipastoril. Revista Scientia Agricola, Piracicaba, v. 67, n. 5, p. 598-603, 2010.

PACIULLO, D. S. C.; GOMIDE, C. A. M.; CASTRO, C. R. T.; FERNANDES, P. B.; MULleR, M. D.; PIRES, M. F. A.; FERNADES, E. N.; XAVIER, D. F. Características produtivas e nutricionais do pasto em sistema agrossilvipastoril, conforme a distância das arvores. Revista Pesquisa Agropecuária Brasileira, Brasília, v. 46, n. 10, p. 1176-1183, 2011.

REIS, G. L.; LANA, A. M. Q.; EMERENCIANO-NETO, J. V.; LEMOS-FILHO, J. P.; BORGES, I.; LONGO, R. M. Produção e composição bromatológica do capimmarandu, sob diferentes percentuais de sombreamento e doses de nitrogênio. Revista Jornal Biosciência, Uberlândia, v. 29, n. 5, p. 1606-1015, 2013.

SANTOS, M. E. R.; FONSECA, D. M.; SILVA, G. P.; PIMENTEL, R. M.; CARVALHO, V. V.; SILVA, S. P. Estrutura do pasto de capim-braquiária com variação de altura. Revista Brasileira de Zootecnia, Viçosa, MG, v. 39, n. 10, p. 2125-2131, 2010.

SILVA, F. de A. S.; AZEVEDO, C. A. V. Versão do programa computacional Assistat para o sistema operacional Windows. Revista Brasileira de Produtos Agroindustriais, Campina Grande, v. 4, n. 1, p. 71-78, 2002

SILVA NETO, S. P.; SANTOS, A. C.; LEITE, R. L. L.; SILVA, J. E. C.; NEVES NETO, D. N.; RODRIGUES, M. O. D.; ALENCAR, N. M. Integrating forest-pasture: Spatial analysis and delineation of zones of litter production and nutrient return. Semina: Ciência Agrarias, Londrina, v. 36, n. 6, p. 4377-4400, 2015. Suplemento 2.

SOARES, A. B.; SARTOR, L. R.; ADAMI, P. F.; VARELLA, A. C.; FONSECA, L.; MEZZALIRA, J. C. Influência da luminosidade no comportamento de onze espécies forrageiras perenes de verão. Revista Brasileira de Zootecnia, Viçosa, MG, v. 38, n. 3, p. 443-451, 2009.

SOUZA, L. F.; MAURICIO, R. M.; GONCALVES, L. C.; SALIBA, E. O. S.; MOREIRA, G. R. Produtividade e valor nutritivo da Brachiaria brizantha cv. Marandu em um sistema Silvipastoril. Revista Arquivos Brasileiros de Medicina Veterinária e Zootecnia, Belo Horizonte, v. 59, n. 4, p. 1029-1037, 2007.

YOKOYAMA, L. P.; FILHO, A. V.; BALBINO, L. C.; OLIVEIRA, I. P.; BARCELLOS, A. O. Avaliação econômica de técnicas de recuperação de pastagens. Revista Pesquisa Agropecuária Brasileira, Brasília, v. 34, n. 8, p. 1335-1345, 1999. 